\title{
'Alles is politiek, maar politiek is nie alles nie': Het Kuitert gelyk?
}

\author{
Willem S Vorster
}

\begin{abstract}
'Everything is politics but politics is not everything': A critical discussion of Harry Kuitert's viewpoint on faith and politics.

A critical review is given of Kuitert's position on faith and politics developed in one of his recent publications. After a general survey, the idea of the two regiments to which Christians belong, is discussed. Then attention is paid to the source(s) from which Christians derive principles for political and social decisions. The implications of Kuitert's views are summarised in a next section. In conclusion the question whether Kuitert is correct is discussed with a view to the South African situation.
\end{abstract}

Die boek van die Amsterdamse hoogleraar in Sistematiese Teologie aan die Vrije Universiteit, HM Kuitert, Alles is politiek maar politiek is niet alles: Een theologisch perspectief op geloof en politiek, wat reeds in 1985 by Ten Have in Baarn verskyn het, verdien meer as ' $n$ gewone resensie. Daarom was dit nie vir my moeilik om ja te sê op die versoek om die vierde druk wat in 1986 verskyn het, krities te bespreek nie. Nie alleen was dit die teologiese boek waarvan daar die meeste eksemplare gedurende 1985 in Nederland verkoop is nie, in Engels en Duits vertaal is nie, resensies uitgelok het uit alle oorde nie, televisie-diskussies in Nederland ontlok het tussen Kuitert en byvoorbeeld Schillebeeckx nie, maar Kuitert neem in hierdie boek ' $n$ standpunt in wat tipeer is as 'Een schadelijk virus, dat om zich heen grijpt' en die mens in twee deel (Verbeek 1986: 10). Die rede waarom dit vir my belangrik lyk dat hierdie boek ons aandag op hierdie stadium in Suid-Afrika verdien, is juis omdat die debat oor Kerk en politiek, geloof en politiek en teologie en politiek uit soveel oorde en uit soveel uiteenlopende uitgangspunte hier ter lande benader word en daar reeds tekens is dat Christene mekaar moeilik kan vind en selfs nie meer bereid is om mekaar se standpunte te probeer verstaan nie. Teoloë en kerkleiers, lidmate en politici spreek hulle uit oor die onderwerp, in dokumente so uiteenlopend soos Kerk en samelewing. The kairos document, rubrieke in dag- 
blaaie, kerklike tydskrifte, en ander openbare media. Elkeen weet beter wat moet en nie mag nie en veral ook wat die wil van God vir die oplossing van maatskaplike en politieke probleme in Suid-Afrika is. Omdat daar vanuit soveel verskillende teologiese perspektiewe deur verskillende deelnemers aan die 'debat' na die werklikheid van die 'kerk' in Suid-Afrika gekyk word, en daar selfs al sprake is van 'n ernstige konflik tussen kerk en staat, kan 'n bespreking van Kuitert se genoemde publikasie help om te verduidelik waarom daar grondige rede bestaan om krities na te dink oor 'kerk', geloof, teologie en politiek. In die hieropvolgende bespreking is dit nie moontlik om die hele boek aan die orde te stel nie. Ek gaan die sake uitlig en krities bespreek wat vir my van die grootste belang lyk vir die Suid-Afrikaanse situasie. Daar sal uiteraard in gedagte gehou moet word dat Kuitert (1986: 11) eksplisiet sê dat hy die boek met die oog op die Nederlandse situasie geskryf het. Wat in Nederland aan die gang is, is nie noodwendig van toepassing op Suid-Afrika nie. Desondanks is wat in Nederland oor die 'kerk', geloof, teologie en politiek gesê word nie onbelangrik vir wat ons hier oor die onderwerp dink nie. Ons is immers as Christene almal deel van die een liggaam van Christus en daarom word ons genoodsaak om saam te dink oor so 'n belangrike onderwerp.

Daar moet vooraf opgemerk word dat dit vir baie ' $n$ verrassing was om hierdie teoloog wat deur die jare heen bekend geword het vir sy verfrissende denke oor baie teologiese kwessies juis op hierdie manier te hoor praat. Dit is gevolglik ook nie vreemd dat daar hoofsaaklik 'n tweërlei reaksie op die boek se verskyning was nie. Aan die een kant was daar hewige teenreaksie en aan die ander stilswye. Dit is veral opmerklik dat die boek in Suid-Afrika nie na my beste wete wye reaksie uitgelok het nie. Hierdie verskynsel berus op verskillende gronde wat nie hier ontleed sal word nie omdat die fokus op die vraag val of Kuitert gelyk het. Indien Kuitert se standpunt korrek is, het dit allerlei implikasies vir die verskillende uiteenlopende teologiese standpunte wat tans ingeneem word oor die kwessie van geloof en politiek. Dit sal hieronder duidelik word.

Die twee sake wat ek uitkies vir bespreking is die relasie tussen 'heil' en 'welsyn', 'n onderskeid wat Kuitert noukeurig uitwerk, en die vraag oor waar die Christen aanwysings vandaan kry om korrekte politieke besluite te neem. Albei die sake het direk met Kuitert se ontwerp te make en daarom word dit op hierdie wyse aangepak. Daar is egter 'n aantal algemene kwessies wat van wesenlike belang is om Kuitert te 
verstaan wat vooraf aan die orde gestel sal word. 'Kerk' verwys in die artikel in die algemeen na die versamelnaam vir alle denominasies, of die versameling van gelowiges, vandaar die aanhalingstekens. In die res van die stuk sal dit weggelaat word.

\section{UITGANGSPUNTE}

Die titel van die boek maak dit duidelik dat Kuitert erns maak met die feit dat alles, selfs die kerk, bewustelik of onbewustelik deel uitmaak van die politieke arena maar dat politiek nie vir die Christen alles is nie. Daar is meer as politiek. Hiermee maak hy 'n belangrike onderskeid tussen kerk, geloof, teologie en politiek, wat soos ons later sal sien, neerkom op ' $n$ baie sterk skeidende onderskeid. Daar kom in die boek twee onderwerpe breedvoerig aan die orde, naamlik' $n$ kritiese aanval op die verpolitisering van die kerk en geloof en ' $n$ afwysing van die kerk se uitsprake oor politieke en maatskaplike vraagstukke. Hierdie twee sake het te make met Kuitert se opvattings oor heil en welsyn wat hy in agtien hoofparagrawe (subhoofstukke) wat deel vorm van vyf hoofstukke, aan die orde stel.

Vir Kuitert het politiek twee komponente, naamlik ideale en die verwesenliking daarvan deur die werf van mag. Dit het betrekking op sowel politieke as maatskaplike kwessies. Teologie daarenteen is nie ' $n$ politieke teorie nie en teoloë is nie bevoeg om vanuit die teologie politieke en maatskaplike vraagstukke aan te spreek nie omdat teologie hulle nie daarvoor kan toerus nie. Teologie kan dit nie wees nie omdat dit ' $n$ universitêre dissipline is waarin menslike uitsprake oor God en sy heil gemaak word, hierdie uitsprake getoets word en nuwe uitsprake hieroor gemaak word wat waarheidsgetrou moet wees. Teologie gaan om 'n 'predik-ontwerp', dit wil sê, wat oor die heil van God gepreek moet word. Selfs politiek kan hierin opgeneem word op voorwaarde dat die waarheidsgehalte daarvan weer getoets word. Juis in die lig hiervan kan teologie nooit ' $n$ teorie vir praxis wees nie omdat teologie nie verklaringe soek vir politieke of maatskaplike probleme nie. Omdat die instrumentarium daarvoor in die teologie ontbreek, kan die teologie nie sodanige probleme deurgrond nie. Maar die teoloog is naas teoloog ook burger en daarom is die relasie geloof en politiek ook van wesenlike belang.

Geloof het betrekking op wat geglo word sowel as op vertroue. 'n Burger wat ook 'n Christen is, laat nie hierdie geloof tuis nie. Dit 
beteken egter nie dat 'n Christen in die geval van maatskaplike en politieke vraagstukke handelingsdirektiewe uit sy/haar geloof in enige van die twee genoemde betekenisse kan aflei nie. Dit beteken alleen dat die geloofstradisie oor die bepaalde kwessie geraadpleeg word om te sien hoe ander Christene oor sodanige sake oordeel of geoordeel het. Soos teologie, vorm geloof ook nie die bron vir aanwysings oor politieke en maatskaplike vraagstukke nie. Dit bring ons by die derde kombinasie, naamlik kerk en politiek.

Net soos teologie nie geloof is nie en geen een van beide bron is vir handelingsdirektiewe oor politieke en maatskaplike vraagstukke nie, is kerk nie teologie of geloof nie, ook nie die burger wat sy geloof by die huis laat nie. Die kerk is ' $n$ versameling van ' $n$ verskeidenheid van gelowiges wat saam 'n gemeenskap vorm, selfs 'n sosiale faktor naas ander sosiale faktore. Om die geloof nie tuis te laat nie beteken dus om nie te aarsel om die kerk in die politieke arena sprekend en handelend in te voer nie. Omdat daar egter in die kerk 'n verskeidenheid gelowiges is met uiteenlopende politieke oortuigings word dit moeilik om van die kerk ' $n$ instituut te maak wat polities optree en spreek.

Kuitert se uiteindelike oogmerk is om die verpolitisering van die kerk teen te werk en die vermoë van die kerk om politieke uitsprake te maak, te bevraagteken. Hy spreek sy kommer uit oor die feit dat die politieke uitsprake van die kerk polarisasie binne die kerkgenootskappe in die hand werk en die onvermoë van kerkleiers om in te sien dat samelewingsvraagstukke deur partypolitieke magsvorming opgelos word en moet word. Wanneer 'n kerk gevolglik via amptelike uitsprake oor belangrike politieke kwessies uitsprake maak, betree die kerk die terrein van die politiek en kom die politiek die kerk binne. Politisering ruïneer trouens die Christelike kerk en wel om die volgende redes volgens Kuitert (1986: 179vv): Dit bring in die eerste plek die kerk in teenspraak met hoe die kerk hom self interpreteer. Die rede waarom die kerk uitsprake maak oor maatskaplike en sosiale kwessies is omdat die kerk 'n magsfaktor word. Maar wat legitimeer hierdie uitsprake? Weer mag, maar hierdie keer mag in geestelike sin. Die mag van die Heilige Gees wat die kerk in staat stel om te praat. In die geval van politieke en maatskaplike uitsprake word die sosiale en geestelike mag van die kerk egter vermeng omdat die uitsprake deur geestelike mag gelegitimeer word. Hiermee word die kerk ontrou aan homself omdat hy'n politieke mag word. In die tweede plek saal politisering van die kerk die kerk met 'n rol op waarvoor die kerk nie toegerus is nie. Die kerk kan geen politieke subjek wees nie. Kernwapens moet die wêreld uit, maar 
watter politieke stappe daarvoor nuttig is, kan kerkleiers nie beter as politici bepaal nie. Derdens haal politisering van die kerk politiek op die manier van die politiek die kerk binne. Politiek is magstryd en dit impliseer reëls wat nie in die kerk tuishoort nie. In die vierde plek verkerklik politisering ook nog die politiek. Dit sal meebring dat politiek deur kerklike kanale bedryf word en sodoende word daar meegewerk aan die ondergang van parlementêre demokrasie. Dit beteken egter nie dat Christene nie moet deelneem aan die politiek nie. Hulle moet juis. Maar die kerk verloor sy karakter as die kerk as kerk begin deelneem aan die politiek. Daar is egter uitsonderings. In noodgevalle moet die kerk instaan vir die politiek. Dit gebeur byvoorbeeld in situasies waarin magsvorming via politieke partye verbode is of politieke partye nie bestaan nie. 'Een goed voorbeeld is Zuid-Afrika: wie moet stem en steun aan de vernederde zwarten en kleurlingen geven, als deze zelf geen macht mogen vormen via partij en parlement?' (1986: 185).

Hierdie algemene uitgangspunte werk Kuitert in detail uit. Maar hoe?

\section{OOR HEIL EN WELSYN BY KUITERT}

Hoewel die boek baie detail bevat wat die hoofstandpunt van Kuitert onderbou, is die grondoortuiging waarvan Kuitert uitgaan, die skeiding tussen twee ryke waarby die Christen betrokke is, of anders gesê, die onderskeid wat daar volgens hom bestaan tussen heil en welsyn of skeppingsheil. 'n Mens sou Kuitert se aanval op die verpolitisering van die kerk of sy kritiese afwysing van die vermoë van die kerk om politieke uitsprake te maak moeilik kon begryp sonder die grondaanname van die sogenaamde 'tweerykeleer' en die daarmeegepaardgaande skeiding tusen die heil van God en die welsyn van die mense. In ' $n$ baie lang aanloop onderbou Kuitert hierdie skeiding met verskillende soorte argumente waarop daar ongelukkig nie binne die beskikbare ruimte ingegaan kan word nie.

Hoewel in eie idioom, hanteer Kuitert hier 'n model van interpretasie wat deur die eeue heen van toepassing gemaak is ten opsigte van die rol van die kerk in die maatskappy. Of anders gesê: Kuitert is van oortuiging dat die Christen betrokke is by twee ryke en dat die heil van die mens onderskei moet word van sy welsyn op aarde. Hierdie gronstelling is niks nuuts nie. Dit is selfs nie nuut in die gereformeerde 
tradisie waarbinne hy sy teologie beoefen nie. Wat wel nuut is, is die manier waarop hy die tweerykeleer uitbou en die feit dat hy binne die huidige omstandighede ' $n$ sterk saak probeer uitmaak vir die skeiding van kerk, geloof, teologie en politiek op grond van die tweerykeleer, en dit in 'n teologiese konteks waarbinne mens dit allermins sou verwag. Dit blyk duidelik uit die reaksies in Nederland oor die inhoud van Kuitert se redenasies.

Die vraag wat aan die orde gestel word, is: Hoe stel Christene hulle die relasie tussen God en die samelewing voor? Aangesien daar verskillende teologiese modelle is met behulp waarvan die vraag hanteer word, is dit ook belangrik om te weet watter teologiese model hierdie relasie die beste verklaar en die meeste vrae oor hierdie relasie oplos. Die oudste en eenvoudigste model is die teologiese konstruksie van 'n teokrasie. Dit beteken dat die samelewing direk deur God regeer word. Hy gee die wette deur middel van die priesters, profete en soortgelyke bemiddelaars en regeer deur die ampte oor alle fasette van die lewe. Van die staat tot die gesin word so direk in relasie tot God gestel. Voorbeelde hiervan is die teokrasie in die Ou Testament, in Islam en ook Geneve onder die regime van Calvyn. In terme van vandag gesien, sou dit beteken waar kerk en staat saamval, ons met 'n teokrasie te make het. Soos in Iran onder die Ayatolla Khomeini en sy godsdienstige helpers gesien kan word, het hierdie middelaars absolute gesag. Daar is geen hoër beroep moontlik nie omdat hierdie helpers in die naam van God optree. Die mens ontvang derhalwe ook sy handelingsdirektiewe hier direk van God deur bemiddeling van die godsdienstige amptenare.

'n Ander model waarbinne hierdie relasie verklaar word, is die sogenoemde tweerykeleer wat veral deur Luther bekendheid verwerf het, hoewel die idee reeds deur Augustinus en selfs vroeër uitgewerk is (vgl Roldanus 1985). Die gedagte van die Christendom wat as congregatio fidelium regeer word op grond van kerklik-kanoniese en Romeinssiviele reg deur die pous en die keiser as aardse dienaars van die onsigbare hoof, Jesus Christus en die gedagte van 'n corpus christianum van die middeleeue het onder aanslag van die sekularisasie begin verbrokkel. Vir Luther was dit duidelik dat die terrein van die mens se daaglikse lewe los gesien kan word van die kerk en in die lig daarvan ontwikkel hy sy beroemde tweerykeleer. Met behulp van sy gedagtes oor die verhouding wet en evangelie redeneer hy dat, indien alle mense Christene was, dit moontlik sou wees om die wêreld na die maatstaf van die evangelie, met name die bergrede te regeer. 
Omdat dit nie die geval is nie, het God twee regimente ingestel en leef die Christen tegelyk onder die regiment van die evangelie en van die wêreld. Die veronderstelling is derhalwe dat die kerk en die volk anders as by die teokrasie nie saamval nie. Die Christen het beide met die kerk en die evangelie van die kerk (die geestelike ryk) asook met die staat en die ordeninge van die staat (die wêreldlike ryk) te make (vgl verder Durand 1978: $18 \mathrm{vv}$ ). Wat is nou die relasie tussen God en samelewing binne hierdie model?

In sy klassieke vorm kom die direktiewe vir die samelewing en die orde daarvan van God in die leer van die twee ryke voor. Dit gebeur op 'n indirekte manier, nie deur openbaring van God aan sy helpers nie, maar deur skeppingsordeninge. So staan God in relasie tot die maatskaplike en politieke orde. 'n Ander vorm van die denkmodel is om te sê die natuur leer self wat goed en leersaam is vir mens en samelewing. Daar word ook gepraat van algemene openbaring. Die belangrike punt is dat in elkeen van hierdie denkmodelle binne die tweerykeleer, die handelingsdirektiewe uit die skepping of die natuur afkomstig is en dat ook Christene hulle handelingsdirektiewe hier vind. Kortom, 'n mens hoef nie 'n Christen te wees om ten opsigte van die maatskaplike en politieke orde kennis en insig te hê nie. Dit beteken verder dat die kerk nie die reg het om aan die staat politieke en maatskaplike direktiewe voor te skryf nie, omdat die kerk nie soos in 'n teokrasie kan aanspraak maak op direktiewe wat spesiaal aan die handlangers van God geopenbaar is en word nie (vgl Kuitert 1986: 103).

Die gedagte van skeppingsordeninge word tereg deur Kuitert (1986: 103) van die hand gewys. Alles wat die kerk skeppingsordeninge genoem het, van die huwelik tot by die politieke orde, bestaan nie vanaf die skepping nie. Dit is produkte van 'n historiese ontwikkeling wat nog steeds verander. Hiermee is die wêreld gesekulariseer (Troeltsch), of soos Kuitert dit stel, leeg wat God betref. Sodoende verander die tweerykeleer totaal en kry ons ' $n$ tweeheid van die wêreld aan die een kant met sy eie politieke en maatskaplike probleme wat so goed as moontlik opgelos moet word en aan die ander kant die mens as persoon. Hierdie persoon het sy eie eise om persoon te wees in 'n leë wêreld maar die evangelieboodskap van die Christendom kom hom/ haar hierin tegemoet. Dit anker die mens in God, 'n bowehistoriese werklikheid wat die mens as persoon in staat stel om staande te bly (Kuitert 1986: 104).

Vir Kuitert kom die tweerykeleer daarop neer dat die Christelike kerk 'n ander ryk preek, 'n ryk van die definitiewe ewige heil van God 
waarvan die kerk hom self as ' $n$ voorskot beskou. Die belydenis van die Christelike kerk is nie alleen dat God alles nuut gemaak het in Christus nie, maar ook dat die kerk glo in die ryk van God wat aan die kom is. Wie in Christus is, is daarom 'n nuwe skepping, maar dit beteken nie dat die ryk van God steeds aan die kom is nie. Daarom kan daar volgens hom geen twyfel daaroor bestaan dat daar tussen heil en welsyn onderskei moet word nie. Heil het te make met die inhoud van die evangelie van Jesus Christus: Die vergewing van sondes, vrede met God, die nuwe lewe en ewige geborgenheid. Skeppingsheil of welsyn daarenteen het te make met maatskaplike en politieke heil wat nie ewige heil is nie. Heil kan nie as welsyn bestaan nie omdat die evangelieboodskap juis te make het met die dinge wat hierbo genoem is as inhoud van ewige heil. Hier kan daar teruggeval word op die klassieke teologiese insig van God as skepper en bewaarder van sy skepping. Nie skeppingsordeninge nie, maar God as die skepper wat nie die mens en die wêreld in die steek laat nie. Daar bestaan so iets soos heil as welsyn, skeppingsheil, of binnewêreldse heil - ook daar waar die heil van die evangelie nie ervaar of geglo word nie omdat God nie die skepping in die steek laat nie. Vandaar dan die tweeheid wat vir Christene bestaan omdat God die skepper en bewaarder met sy wêreld omgaan maar ook die versoener en verlosser is. Slegs Christene ken hierdie tweeheid omdat hulle glo aan die 'Ander ryk' naamlik die ryk van God wat nog kom (Kuitert 1986: 141-146).

Omdat heil nie welsyn of skeppingsheil is nie, mag die een ryk ook nie volgens Kuitert (1986: $147 \mathrm{vv}$ ) met die ander gelyk gestel word of verwar word nie. As heil en welsyn verwar word, word maatskaplike en politieke heil tot inhoud gemaak van die Christelike verkondiging en dit is nie moontlik nie. 'Wie in Christus is, is een nieuwe schepping en niet: wie in een democratische, revolutionere of wat voor politieke orde ook leeft' (1986: 147). Politieke orde kan nie 'n nuwe skepping maak nie, dit kan alleen maar skeppingsheil bevorder of afbreek. Vandaar die belangrikheid daarvan.

Die onderskeid tussen heil en welsyn het nog verdere implikasies. Terwyl heil 'n gawe van God is wat mense uit genade ontvang, is skeppingsheil iets waarvoor die mens aanspreeklik is. Daarbenewens help die onderskeid om te verklaar hoe daar ook buite die Christelike kerk heil, dit is skeppingsheil, is. Dit word ook duidelik waarom die kerk en die Bybel nie nodig is om kennis van wat goed en wat sleg is te onderskei nie. Trouens, die Bybel veronderstel dat Israel lank voor die ontstaan daarvan reeds oor morele kennis beskik het. Beginsels van 
humaniteit, kan soos in die klassieke teologie, tot God self teruggelei word omdat hy hom as skepper nie onbetuig laat nie.

\section{WAAR KRY 'N CHRISTEN AANWYSINGS VIR POLITIEKE HANDELING?}

Daar is reeds hierbo opgemerk dat Kuitert betoog het dat ons in die sogenoemde skeppingsordeninge nie te make het met handelingsdirektiewe wat van God afkomstig is nie, maar dat die wêreld gesekulariseer is, leeg is wat God betref. Verskeie pogings is aangewend om hierdie leegheid weer te vul sodat daar tog vanuit die teologie handelingsaanwysings kan kom. Kuitert behandel onder andere die pogings van Barth, Bonhoeffer, Moltmann en die Latyns-Amerikaanse bevrydingsteoloë om hierdie leegheid vanuit verskillende aspekte van die teologie te vul. Hy kom egter tot die gevolgtekking dat dit sonder sukses gebeur het:

'... de directieven die we zagen - en zien - hanteren door de theologie, waren al bekend kwamen ondanks de beweringen van het tegendeel helemaal niet uit de theologie van het ene Woord Gods, uit de christologie of uit de algemene eschatologie maar uit de algemeen menselijke principes van humaniteit en uit rationele analyse van de situasie' (1986: 123).

Hierdie grondstelling onderbou hy verder met 'n bespreking van die onmoontlikheid om die bergrede in die politiek te gebruik en die oortuiging dat dit nie moontlik is om 'messiaanse politiek' te bedryf nie. Selfs al moet daar in die politiek tog gewerk word aan die ideale van vrede, geregtigheid, vryheid en susterskap (1986: 129), en hierdie ideale die messiaanse ideaal van 'n 'heile Welt' verteenwoordig, is 'messiaanse politiek' volgens hom nie haalbaar nie en kan die bergrede ook nie gebruik word as aanwysings of instruksies vir politieke en maatskaplike handelinge nie. Die praktyk wys dit reeds uit. Kuitert (1986: 132) stel dit heel skerp wanneer hy sê: Niemand hou hom/haar in die politiek aan die bergrede nie, selfs nie die linkse of regse Christenpolitikus nie; dit is ook nie moontlik om jou in die politiek aan die bergrede te hou nie en niemand behoort hom/haar in die politiek aan die bergrede te hou nie.

In die debat rondom kernwapens sou ' $n$ konsekwente toepassing van die bergrede immers lei tot navolging van Christus en dit beteken nie 
oorlog nie maar vrede, nie 'n wedloop om wapens nie maar afbreek van vyandskap tussen volke. Met die bergrede in die hand sal mens jou nie alleen teen kernwapens moet wend nie maar ook teen alle moderne wapens. Van die bergrede en politieke situasies soos die in SentraalAmerika en Suid-Afrika sê hy onder andere na aanleiding van Matteus 5: 38-48 dat dit onmoontlik is om vir die slagoffers van apartheid te sê om die bose nie te weerstaan nie en hom die ander wang te draai. Die bergrede kan met ander woorde nie in die politiek toegepas word nie. Die teendeel van wat aan die armes en treurendes ensovoorts in die bergrede beloof word, naamlik dat hulle loon groot is in die hemel, is om armes te bevry van onderdrukking, hongeriges met voedselaksies by te staan of vervolgdes met ' $n$ bevrydingsleër by te staan.

Christene kan kennelik nie die instruksies wat in die bergrede gegee word, opvolg in die praktiese politiek nie. Dit is alleen moontlik wanneer die kerk van hierdie wêreld niks meer verwag en kan verwag nie. Dit is wanneer die kerk bereid is om die weg van onmag en die kruis te gaan en sy hoop te stel op die koninkryk van die hemele en die moed het om ' $n$ 'drop out' te wees. Prakties sou dit beteken om op grond van die geloof diensplig te weier, nie langer belasting te betaal nie of deelname aan ' $n$ siekefonds op te sê. Dit is nie die weg wat deur die meeste Christene gekies word nie. Kuitert (1986: 135-137) se standpunt is ook dat só 'n weg juis nie gekies moet word nie. Hy begrond dit met die volgende argumente:

In die eerste plek het politiek te make met die koester van politieke en maatskaplike ideale en die werf van of behoud van mag om hierdie ideale te verwesenlik. Vir politiek is magstryd dus nodig. As Christene derhalwe invloed wil uitoefen op die realisering van politieke ideale moet hulle teen die instruksie van die bergrede in deelneem aan die stryd om mag.

Tweedens kan Christene nie afsien daarvan om invloed te wil uitoefen nie. Sou hulle dit doen, is die samelewing van so ' $n$ aard dat wie konsekwent van invloed, mag en selfs geweld afsien, dit oorlaat aan geweldenaars.

In die derde plek is dit alleen moontlik om van geweld af te sien, die ander wang te draai of vrywilliglik 'n kledingstuk te gee, dit wil sê die bergrede tot politieke ideaal te verhef as die hele wêreld kerk was. Dan sou ons ons in 'n teokrasie bevind waar kerk en volk saamval. Dit is nòg die feitlike situasie nòg die situasie wat Matteus se Evangelie veronderstel. Soos in die res van die Nuwe Testament oorvleuel die kerk en samelewing mekaar nie in die Evangelie van Matteus nie. Die kerk is 
die begin van 'n burgerskap van ' $n$ heel ander staat. Dit is vir hierdie kerk wat die instruksies van die bergrede opgeteken is, nie vir die politiek nie: '... niet door de Bergrede tot een politiek program te maken, maar door haar tot inhoud van de Christusprediking te maken, verschaft de christelijke kerk de Messias en zijn Rijk entree in deze wereld' (Kuitert 1986: 137). Maar om die bergrede nie tot politieke ideaal te veref nie impliseer geheel en al nie dat die geloof by die huis gelaat word in die politiek volgens Kuitert nie. Ook die bergrede gee derhalwe nie die handelingsaanwysings vir die Christen aan in maatskaplike en politieke optredes nie. Nòg die Woord in die algemeen, nòg die Christologie, nòg die eskatologie, nòg die bergrede is die bron van aanwysings vir die Christen ten opsigte van hierdie sake. Dit is hier waar ons weer moet herinner aan Kuitert se redenasie oor die tweerykeleer ten opsigte van die onderskeid tussen heil en welsyn of skeppingsheil. Dit kom in kort op die volgende neer:

In die eerste plek kan die beginsels vir politieke en maatskaplike handeling onmoontlik uit die evangelie, 'het ene Woord Gods', afgelei word. Die basisbeginsels van humaniteit was reeds daar voor die evangelie ooit verkondig is. Dit geld selfs van Jesus se opvattings oor die politiek. Ook Hy het Hom hierdeur laat lei en daarom behoort Christene hulle ook deur die algemene beginsels van humaniteit wat uit die skepping afkomstig is te laat lei. Verder is dit duidelik dat 'n mens nie ' $n$ Christen hoef te wees om te weet wat goed en wat sleg is nie. Dit kom wel aan op die doen van wat goed is en nie op die kennis daarvan nie. Heil bestaan ook buite die kerk, naamlik skeppingsheil of welsyn. Die kerk is nie beter toegerus om vir die welsyn van die samelewing te sorg nie. Daar is ander wat dit beter kan doen. Kortom, dit gaan in die tweerykeleer om die twee maniere waarop God met die mense en die wêreld besig is. Hierdie twee maniere is onverwisselbaar omdat skepping nie versoening en verlossing is nie en omgekeerd.

\section{ENKELE IMPLIKASIES}

Die implikasies van hierdie onderskeiding tussen twee ryke het verreikende gevolge vir die manier waarop die kerk en by name Christene hulle in die wêreld uitleef. Christene is nie alleen lede van die kerk nie, hulle is ook vennote van die wêreldryk, die ryk wat deur God se skepping bewaar is. Daarom doen hulle mee aan die magstryd op politieke terrein deur die instrumente wat daarvoor in die politiek 
bestaan. Die kerk kan homself nie as kerk in die politiek begeef sonder om ontrou te word aan wat die kerk kerk maak nie, naamlik lewe uit die Gees wat die kerk ' $n$ nuwe skepping laat wees (Kuitert 1986: 180). Omdat die kerk nie daarvoor toegerus is nie, is dit ook nie die taak van die kerk om die werk van die politiek te dupliseer nie. Indien dit gebeur, halveer die kerk homself want dan moet die kerk of welsynswerker ò politieke party word. Die kerk is kerk omdat hy iets te vertel het wat geen ander instansie kan vertel nie: Die verhaal van Jesus as die Christus, as openbaring van God as verlosser en versoener (Kuitert 1986: 200-201). In die laaste hoof paragraaf van sy boek redeneer Kuitert (1986: 207-219) dan ook konsekwent met die voorafgaande dat wanneer die toekomsverwagting uit die Christelike geloof weggeneem word dit ' $n$ totaal ander geloof word. Die gevolg hiervan is dat: 'Als maatschappelijk heil alle heil is dat mensen verwachten mogen, is er maar een conclusie mogelijk: dan moet inderdaad alles hier gebeuren, alle geluk hier gesmaakt, alle genot hier genoten en al het verschuldigde hier voldaan. Want wat hier niet wordt ontvangen of afgemaakt, wordt het nergens' (Kuitert 1986: 215).

\section{HET KUITERT GELYK?}

Hierdie is geen gemaklike vraag nie en 'n mens sou eintlik 'n boek oor Kuitert se boek moes skryf om die vraag te beantwoord. Dit is moontlik om Kuitert se voorstel binne die raamwerk waarbinne hy werk, te beoordeel en te vra of hy die model konsistent deurdink en toegepas het. Aangesien daar egter ook ander modelle bestaan met behulp waarvan die vraag na die relasie tussen geloof en politiek of kerk en samelewing hanteer word, kan die model van Kuitert ook aan die hand van die modelle beoordeel word. Omdat die ruimte nie daarvoor bestaan om aan alle aspekte aandag te skenk nie sal daar met algemene opmerkings oor die voorstel van Kuitert volstaan word.

In die eerste plek is dit opmerklik dat Kuitert in Nederland die meeste kritiek ontvang het op sy voorstel om die probleem aan die hand van die tweerykeleer te hanteer (vgl Blei 1986; Heering 1986; Jager 1986; Runia 1985; Van Veen 1986 en Verbeek 1986). Die kritiek kom daarop neer dat die tweerykeleer 'n onnodige skeiding van die Christen meebring en dat dit op Griekse denke berus. Die groot probleem is om ' $n$ brug te slaan tussen die twee ryke. Hoe vind die kommunikasie tussen die twee plaas? Is daar enige kommunikasie? 'Als je die 
constructie toch in praktijk brengt, krig je de gekste dingen. 's Zondags belijd je het credo, je zegt dat je gelooft in de weg die Jezus is gegaan en dat je die volgen wilt. En 's maandags bestel je kruisraketten en doe je mee aan het rijker worden van het rijkste deel van de wereld. Tegelijk blijft je je Christen noemen' (Verbeek 1986: 10). Hierdie dilemma is inherent aan die tweerykeleer maar dit word ook nie opgelos deur byvoorbeeld die erkenning van die totale heerskappy van God nie. Dit merk mens reeds op by die worsteling van Bonhoeffer in sy aandrang daarop dat die kerk alleen Gregoriaans mag sing as hy terselfdertyd sy stem verhef vir die Jode en die kommuniste (vgl Durand 1978: 19) en hom daarom losmaak van die tweerykeleer. Dieselfde gebeur ook ten opsigte van die sogenaamde Gereformeerde Christokratiese model waarvolgens daar geen aspek van die lewe is waarop Christus nie aanspraak maak nie. Tog bestaan daar 'n wesenlike verskil tussen die staat en die kerk. Eersgenoemde vind sy uitgangspunt in die algemene genade van God se handhawing van sy skepping volgens Kuyper, terwyl die kerk sy uitgangspunt het in die besondere genade van Woord en wedergeboorte (vgl Durand 1978: 25). Dit loop uit op die beginsel van soewereiniteit in eie kring en die onderskeiding tussen kerk as instituut en kerk as organisme. Dit is die kerk as organisme wat volgens Kuyper op elke terrein van die lewe sy invloed moet laat geld, selfs die vorming van 'n Christelike politieke party. Die raakpunte hierbo met Kuitert is duidelik. Die gevare daarvan is ook duidelik uit die geskiedenis van die kerke in Suid-Afrika waar die beginsel van die heerskappy van Christus op alle gebiede op grond van hierdie denkmodel erken is, maar die kerk as instituut en as organisme sodanig saamgeval het met die staat dat dit aanleiding gegee het tot die formulering van politieke ideale wat nou allerweë as agterhaal beskryf word en daar in regeringskringe en sommige kerklike kringe opnuut gesoek word na politieke oplossings wat godsdienstig gelegitimeer kan word. Aan die ander kant word daar sodanig onderskei tussen die kerk as instituut en die kerk as organisme dat die kerk as instituut se stem feitlik stil gemaak word in sake wat deur Kuitert as noodgevalle beskou sou word. Die standpunt dat die kerk 'n profetiese stem mag laat hoor oor maatskaplike en politieke sake op grond van die algemene beginsels van die Woord is algemeen bekend. Maar dit is ook bekend dat beide dr Treurnicht, leier van die opposisie (vgl Durand 1978: 27), en die Staatspresident, mnr PW Botha, leier van die regerende party (vgl sy korrespondensie met swart kerkleiers), nie genoeë daarmee neem dat die kerk of kerkleiers hulle as Christene uitspreek oor konkrete aange- 
leenthede wat die politiek raak nie. Hier sou 'n mens wou sê Kuitert se voorstel nie geld nie omdat dit van die Christen 'Thuis een Franciscus en buiten een Machiavelli' maak (Heering 1986: 16).

Dit bring ons by ' $n$ volgende opmerking. Teologiese modelle word nie alleen bepaal deur modelle, dit wil sê teologiese konstruksies nie. Hulle word ook bepaal deur die manier waarop Christene hulle werklikheid ervaar en konstrueer. Hiermee bedoel ek nie in die eerste instansie die rol van konteks en gevolglik van konteksbepaalde kennis nie. Dit is 'n gegewenheid dat alle kennis, insluitend teologiese kennis sosial bepaal is en daarom uitsien soos wat dit daar uitsien (vgl die kritiek van Van Heijst 1986 op Kuitert). Wat ek hier in gedagte het, is die kwessie van die perspektief waaruit ' $n$ teologiese probleem benader word. Dit is duidelik dat Kuitert se veronderstelling dat politieke handeling alleen op politieke gronde verantwoord kan word, weinig rekening hou met byvoorbeeld die geloof aan die inkarnasie van Christus waarvolgens dit onmoontlik is om uit te sluit dat God met sy heil (nie welsyn) ook op aarde en ook in die politiek besig is nie (vgl ook Heering 1986: 17). Dit is hierdie geloof aan of perspektief op die menswording van Christus en sy identifikasie met die noodlydendes wat aanleiding gegee het tot die ontstaan van verskillende vorme van teologieë van bevryding. Hoe 'n mens hierdie teologieë ook al mag beoordeel, een ding kan nie ontken word nie. Bevrydingsteologie het vernuwend ingewerk op Christene wat sonder hoop voortgeploeter het. Ten spyte van al die kritiek wat ons kan loods teen verskillende vorme van bevrydingsteologieë staan dit vas dat die inkarnasie van Christus vormend ingewerk het op die teologiese konstruksies. Hierdie soort teologie dwing alle teoloë terug na die tekenbord, op dieselfde wyse as wat die vrylating van die slawe Christene teruggedwing het na die tekenbord. Selfs Kuitert moet teruggedwing word na die tekenbord omdat daar meer teologiese perspektiewe op die mark is as die waarmee die tweerykeleer werk met behulp waarvan die kwessie van geloof en politiek aangespreek kan word. 'n Mens sou byvoorbeeld graag wou sien dat Kuitert aandag sou geskenk het aan die kwessie van die verband tussen natuur en genade soos ontwikkel in die dokumente van die Tweede Vatikaanse konsilie. Die positiewe houding wat in Gaudium et Spes ingeneem word ten opsigte van die wêreld sou Kuitert tog miskien daartoe kon bring om meer erns te maak met die wêreld wat nie meer beskou word as 'n statiese stuk skepping nie maar eerder as die skepping van God wat dinamies voortbeweeg na die voleinding. 'Vir Gaudium et Spes is die wêreld inderdaad ' $n$ mensewêreld en die 
klem val op die sosialisering en vermensliking van die wêreldsamelewing. Die kerk staan daarom nie antiteties teenoor die wêreld nie, maar is ten volle betrokke by hierdie proses van sosialisering en humanisering' (Durand 1978: 4). Is daar nie tekens van die ewige heil ook in die verdorwe aarde reeds teenwoordig nie? Dit is bekend dat as gevolg van hierdie en ander benaderings in Vaticanum II die Derde Wêreld begin momentum kry het. As gevolg van sy vrese vir die politisering van die kerk maak Kuitert nie erns met sodanige beskouinge wat ten grondslag lê van baie teologiese aansprake op die politiek nie. Dit beteken egter nog nie dat ek daarmee wil beweer dat mens nie aan die ander kant erns moet maak met die gevare van die verpolitisering van die kerk nie. Allermins. Kuitert het gelyk dat verpolitisering van die kerk die kerk ruïneer!

Kuitert het verder ook gelyk dat daar nie algemene handelingsdirektiewe vir die politiek of die maatskappy uit die Bybel of die bergrede of watter deel van die Ou of die Nuwe Testament afgelei kan word nie (vgl egter Asendorf 1986 asook Blei 1987a). Sodanige pogings het nog altyd gelei tot inlegkunde of legitimasie van eie standpunte. Daarvan is die geskiedenis van die uitleg van die Bybel 'n sprekende voorbeeld. Met die Bybel in die hand is daar in Suid-Afrika aangetoon dat apartheid geldig is. Vandag word daar op grond van die Bybel deur baie van dieselfde uitleggers die teenoorgestelde beweer. Is daar sprake van verkeerde Skrifuitleg? Die Bybel is 'n geloofsboek, of beter, 'n versameling van geloofsboeke waaraan Christene hulle oriënteer en moet oriënteer. Maar nêrens in die Ou of die Nuwe Testament word daar enige uitspraak gemaak by wyse van handelingsdirektiewe oor die politieke of maatskaplike situasie in Suid-Afrika in 1988 nie. Wie dit daar iewers lees, lees dit daar in. Daarom het Kuitert een honderd persent reg om te beweer dat daar geen handelingsdirektiewe direk uit die Bybel gehaal kan word nie. Dit geld vir Wit teologie sowel as vir Swart teologie, vir Feministiese teologie sowel as vir anti-feministiese teologie, vir Marxistiese sowel as Kapitalistiese teologie. En bewaar ons van die politici wat hulle politieke besluite met die Bybel legitimeer.

Die rede waarom teoloë in Suid-Afrika weer saam om die tekenbord oor maatskaplike en politieke probleme sal moet gaan sit, is tweërlei van aard. Enersyds moet ons mekaar se teologiese perspektiewe grondig leer ken en mekaar vierkant in die oë gaan kyk, soos die teoloë in die geskiedenis van die kerk maar altyd weer moes gaan doen met die besef dat teologie mensewerk is. Verder moet ons bereid wees om die analises wat ons van die samelewing mak op grond waarvan ons 
politieke oortuigings opbou, oop en bloot te doen. Dit baat nie meer om te ontken dat daar baie maniere is waarop 'n mens na die werklikheid van 'n samelewing mag kyk nie. Die teorieë wat bewustelik of onbewustelik ' $n$ rol speel in ons analises van die samelewing, bepaal die manier waarop ons die werklikheid rondom ons konstrueer. Kairosteoloë en Kerk-en-samelewing-teoloë, om maar by wyse van voorbeeld twee groepe uit te sonder, kan mekaar teologies alleen vind wanneer hulle mekaar se teologieë verstaan en verstaan waarom hulle die werklikheid van die Suid-Afrika verskillend verstaan. Indien hulle mekaar se perspektiewe begryp, sal hulle ook saam daarop aandring by die regering van die dag om insae te kry in wat werklik in Suid-Afrika aan die gang is, omdat daar 'n beperking op insae in die werklikheid gelê is. In hierdie verband kan Kuitert (1986: 159-161) se opmerkings oor die prinsipes wat politiek nodig het en hoe geloof daarin 'n rol speel, die moeite werd wees om saam te probeer uitspel om 'n tafel.

Kuitert kan nie omdat die tweerykeleer nie voldoende rekening hou met die probleme wat hierdie perspektief vir die Christen in die alledaagse lewe inhou nie, Kuitert kan omdat hy genoeg erns maak met die feit dat die mens van die twintigste eeu die verantwoordelikheid moet neem om sonder legitimasie van die Bybel met sy foute en sy prestasies in nederigheid voor God te gaan staan tot getuienis van die wêreld.

\section{Literatuurverwysings}

ASENDORF, U 1986. Die bleibende Bedeutung von Luthers Regimente-Lehre: Politische Orientierung und Handlungsanweisung aus dem Evangelium. Diakrisis 7, 34-41.

BLEI, K 1986. De christen, de kerk en de politiek: voortgezet gesprek met Kuitert. Woord en Dienst 23 Augustus, 309-310.

BLEI, K 1987 a. Een discussie over politiek, geloof en kerk: N.a.v.: H.M. Kuitert/E.Schillebeeckx, Gesprek tussen twee vuren E. Schillebeeckx, Als politiek niet alles is ... Evangelisch Commentaar 25 September, 5-7.

BLEI, K 1987 b. Een discussie over politiek, geloof en kerk: N.a.v.: H.M. Kuitert/E. Schillebeeckx, Gesprek tussen twee vuren E. Schillebeeckx, Als politiek niet alles is ... Evangelisch Commentaar 9 Oktober 1987, 6-8.

DURAND, JJF 1978 (Du Randt sic!). Kontemporêre modelle vir die verhouding van kerk en samelewing, in Vorster, WS (Ed/Red) Church and society/Kerk en samelewing. Pretoria: Universiteit van Suid-Afrika.

HEERING, H 1986. Thuis een Franciscus en buiten een Machiavelli. Hervormd Nederland Magazine 4 Januarie, 42/1, 16-19.

JAGER, O 1986. Een vrouw met een droom of een vrouw in verwachting? Hervormd Nederland Magazine 8 Februari, 20-23.

KUITERT, HM 1986. Alles is politiek maar politiek is niet alles: Een theologisch perspectief op geloof en politiek. Baam: Ten Have.

MULDER, DC 1986. Niet alles is politiek. Evangelisch Commentaar 24 Januari, 14-16. 
ROLDANUS, J 1985. Tweeërlei burgerschap van de chirsten: Vroegchristelijke modellen van terughouding en engagement t.o.v. de politieke gemeenschap. Kerk en theologie 36, 265-283.

RUITENBERG, LH 1986. Politiek en kerk. Woord en Dienst 8 Februari, 45-46.

RUNIA, K 1985. Kuitert: Nu tegen de stroom in van recente traditie: Terugkeer tot de twee-rijkenleer, kerk zoekt geen macht. Centraal Weekblad 15 November, 6-8.

VAN VEEN, JE 1986. Interkerkelijk werkverband of christelijke organisatie? Kanttekeningen bij modellen over de verhouding geloof, kerk en politiek. Evangelisch Commentaar 21 Maart, 10-12.

VAN HEIJST, A 1986. Blanken westerse mannen, daar blijft het bij. Hervormd Nederland Magazine 1 Maart, 27-29.

VERBEEK, H 1986. Kuitert hakt mens in tweeën: Een schadelijk virus, dat om zich heen grijpt. Heroormd Nederland Magazine 18 Januari, 10-12. 